\title{
Does Gender Affect Rectal Temperature Cooling Rates? A Critically Appraised Topic
}

\author{
Kayla E. Boehm and Kevin C. Miller
}

\begin{abstract}
Clinical Scenario: Exertional heat stroke (EHS) is a medical emergency characterized by body core temperatures $>40.5^{\circ} \mathrm{C}$ and central nervous system dysfunction. An EHS diagnosis should be immediately followed by cold-water immersion (CWI). Ideally, EHS victims cool at a rate $>0.15^{\circ} \mathrm{C} / \mathrm{min}$ until their temperature reaches $38.9^{\circ} \mathrm{C}$. While generally accepted, these EHS treatment recommendations often stem from research that examined only males. Since gender differences exist in anthropomorphics (eg, body surface area, lean body mass) and anthropomorphics impact CWI cooling rates, it is possible that CWI cooling rates may differ between genders. Clinical Question: Do CWI rectal temperature $\left(T_{\text {rec }}\right)$ cooling rates differ between hyperthermic males and females? Summary of Findings: The average $T_{\text {rec }}$ cooling rate across all examined studies for males and females was $0.18(0.05)$ and $0.24(0.03)^{\circ} \mathrm{C} / \mathrm{min}$, respectively. Hyperthermic females cooled $\sim 33 \%$ faster than males. Clinical Bottom Line: Hyperthermic females cooled faster than males, most likely because of higher body surface area to mass ratios and less lean body mass. Regardless of gender, CWI is highly effective at lowering $T_{\text {rec }}$. Clinicians must be able to treat all EHS victims, regardless of gender, with CWI, given its high survival rate when implemented appropriately. Strength of Recommendation: Moderate evidence ( 2 level 3 studies) suggests that females cool faster than males when treated with CWI following severe hyperthermia. Despite gender differences, cooling rates exceeded cooling rate recommendations for EHS victims (ie, $0.15^{\circ} \mathrm{C} / \mathrm{min}$ ).
\end{abstract}

Keywords: females, heat stroke, hyperthermia, males, sex

\section{Focused Clinical Question}

Do cold-water immersion $(\mathrm{CWI})$ rectal temperature $\left(T_{\text {rec }}\right)$ cooling rates differ between hyperthermic males and females?

\section{Summary of Search, "Best Evidence" Appraised, and Key Findings}

- We searched for studies that used CWI (water temperature $<20^{\circ} \mathrm{C}$ ), the gold standard treatment for exertional heatstroke, ${ }^{1}$ to treat hyperthermic males and females (eg, $\mathrm{T}_{\text {rec }} \geq 39.5^{\circ} \mathrm{C}$ ).

- Nine studies met the search criteria; however, 6 studies were excluded because data were not separated by gender. Three studies $^{2-4}$ met our predetermined inclusion and exclusion criteria for this critically appraised topic (CAT) study.

- Two studies ${ }^{2,3}$ observed clinically meaningful differences, with females having higher $T_{\text {rec }}$ cooling rates. The third study ${ }^{4}$ observed no differences in $T_{\text {rec }}$ cooling rates between males and females (Table 1). The average effect size for all studies analyzed in this $\mathrm{CAT}^{2-4}$ was 2.4 (ranged from 0 to 3.9 ).

- The average $T_{\text {rec }}$ cooling rates across all examined studies ${ }^{2-4}$ were $0.18(0.05)$ and $0.24(0.03)^{\circ} \mathrm{C} / \mathrm{min}$ for males and females, respectively. Although hyperthermic females cooled $\sim 33 \%$ faster than males, both genders cooled faster than

The authors are with the School of Rehabilitation and Medical Sciences, Central Michigan University, Mount Pleasant, MI, USA. Miller (mille5k@cmich.edu) is corresponding author. recommendations for exertional heat stroke (EHS) victims (ie, $\left.0.15^{\circ} \mathrm{C} / \mathrm{min}\right) .^{5}$

\section{Clinical Bottom Line}

There is moderate evidence that hyperthermic females cool faster than males. In the studies analyzed, ${ }^{2-4}$ hyperthermic males typically needed to be immersed in cold water for 4.3 (3.0) minutes longer than hyperthermic females. Despite the apparent cooling differences between genders, CWI continues to be the gold standard treatment for all EHS patients, male or female. $^{5}$

\section{Terms Used to Guide Search Strategy}

- Patient/Client group: Hyperthermic adults

- Intervention/Assessment: Gender (males), sex

- Comparison: Gender (females), sex

- Outcome: Rectal temperature cooling rate

\section{Sources of Evidence Searched}

- PubMed

- CINAHL

- SPORTSDiscus

- Cochrane Library

- ERIC

- Additional articles were obtained by review of reference lists 
Table 1 Characteristics of Included Studies

\begin{tabular}{|c|c|c|c|}
\hline Authors & Armstrong et $\mathrm{al}^{3}$ & DeMartini et al $^{4}$ & ${\text { Lemire et } \mathrm{al}^{2}}^{2}$ \\
\hline Patients, $\mathrm{n}$ & $\begin{array}{l}8000 \text { athletes. } \\
21(35[3] \text { y) were diagnosed with extreme } \\
\text { hyperthermia and either heat exhaustion or } \\
\text { EHS. } \\
17 \text { males (age }=36[12] \mathrm{y}) ; \\
4 \text { females }(\text { age }=32[7] \mathrm{y}) \text {. } \\
\text { *Subject anthropomorphics } \\
\text { not reported. }\end{array}$ & $\begin{array}{l}180,000 \text { athletes }(\sim 10,000 \text { each year). } \\
258 \text { athletes had documented } \\
\text { EHS signs and symptoms } \\
(179 \text { EHS cases reported by gender). } \\
110 \text { males (age }=34[13] \mathrm{y}) ; \\
69 \text { females (age }=36[12] \mathrm{y}) \text {. } \\
* \text { Subject anthropomorphics not reported. }\end{array}$ & $\begin{array}{l}10 \text { males } \\
(\text { age }=25[4] \mathrm{y}, \mathrm{ht}=177.5[5.8] \mathrm{m}, \\
\text { mass }=73.6[9.4] \mathrm{kg}, \\
\text { body fat }=13.8 \%[2.9 \%], \\
\mathrm{LBM}=63.4[7.2] \mathrm{kg}, \\
\text { BSA } / \mathrm{M}=261[16] \mathrm{cm}^{2} / \mathrm{kg}, \\
\left.\text { BSA/LBM }=302[15] \mathrm{cm}^{2} / \mathrm{kg}\right) \\
9 \text { females } \\
(\text { age }=24[3] \mathrm{y}, \mathrm{ht}=165.4[6.8] \mathrm{m}, \\
\text { mass }=64.2[9.3] \mathrm{kg}, \\
\text { body fat }=23.9 \%[6.1 \%], \\
\text { LBM }=48.4[4.5] \mathrm{kg}, \\
\text { BSA } / \mathrm{M}=268[19] \mathrm{cm}^{2} / \mathrm{kg}, \\
\left.\text { BSA } / \mathrm{LBM}=353[17] \mathrm{cm}^{2} / \mathrm{kg}\right)\end{array}$ \\
\hline $\begin{array}{l}\text { Experimental } \\
\text { design and } \\
\text { methods }\end{array}$ & $\begin{array}{l}\text { Retrospective cohort study. } \\
\text { - Subjects ran } \sim 11 \mathrm{~km} \text { in the Falmouth Road } \\
\text { Race in August }\left(24.4^{\circ} \mathrm{C}\left[0.8^{\circ} \mathrm{C}\right], 67 \% \text { [ } 4 \%\right] \\
\text { humidity). } \\
-T_{\text {rec }} \geq 39.4^{\circ} \mathrm{C} \text { for all subjects prior to } \\
\text { treatment. }\end{array}$ & $\begin{array}{l}\text { Retrospective cohort study. } \\
\text { - Subjects ran } \sim 11 \mathrm{~km} \text { in the Falmouth } \\
\text { Road race in August }\left(23.3^{\circ} \mathrm{C}\left[2.5^{\circ} \mathrm{C}\right],\right. \\
70 \%[16 \%] \text { humidity). } \\
\text { - Race participants were included as } \\
\text { subjects if } T_{\mathrm{rec}} \geq 40^{\circ} \mathrm{C} \text { and an EHS } \\
\text { diagnosis was documented. }\end{array}$ & $\begin{array}{l}\text { Quasi-experimental study. } \\
\text { - Subjects ran on a treadmill at } \\
65 \% \mathrm{VO}_{2} \text { max in heat }\left(40.0^{\circ} \mathrm{C} \text {, }\right. \\
\sim 18 \% \text { humidity) until } T_{\text {rec }} \text { reached } \\
39.5^{\circ} \mathrm{C} \text {. }\end{array}$ \\
\hline $\begin{array}{l}\text { Cooling } \\
\text { intervention }\end{array}$ & $\begin{array}{l}13 \text { males and } 1 \text { female were treated by } \\
\text { IWI }\left(1-3^{\circ} \mathrm{C}\right) \text { until } T_{\text {rec }} \text { reached } 39.0^{\circ} \mathrm{C} \text {. } \\
\text { - The subjects' torso and upper legs were } \\
\text { completely immersed. } \\
\text { - No mention of water circulation during } \\
\text { treatment. }\end{array}$ & $\begin{array}{l}\text { All subjects were treated by CWI }\left(10^{\circ} \mathrm{C}\right) \\
\text { in a } 50 \text {-gal tub until } T_{\text {rec }} \text { reached } 38.8^{\circ} \mathrm{C} \text {. } \\
\text { No noted specifications on water } \\
\text { circulation. } \\
\text { - Subjects were immersed in a seated } \\
\text { position. } \\
\text { If arms or legs were not completely } \\
\text { submersed, } \\
\text { then wet ice towels were used to cover } \\
\text { the arms, legs, neck, and head. }\end{array}$ & $\begin{array}{l}\text { All subjects were immersed in a } \\
\text { circulated water bath }\left(2^{\circ} \mathrm{C}\right) \text { until } T_{\text {rec }} \\
\text { reached } 37.5^{\circ} \mathrm{C} \text {. } \\
\text { - Subjects were immersed in a } \\
\text { recumbent position (head and chest } \\
\text { were not fully immersed). }\end{array}$ \\
\hline Results & $\begin{array}{l}T_{\text {rec }} \text { post exercise: } \\
\text { female }=41.9^{\circ} \mathrm{C} ; \\
\text { male }=41.6^{\circ} \mathrm{C}\left(0.6^{\circ} \mathrm{C}\right) \\
\text { Immersion duration: } \\
\text { female }=11 \mathrm{~min} ; \\
\text { male }=17(8) \mathrm{min} . \\
T_{\text {rec }} \text { cooling rate: } \\
\text { female }=0.27^{\circ} \mathrm{C} / \mathrm{min} \\
\text { male }=0.20(0.07)^{\circ} \mathrm{C} / \mathrm{min} .\end{array}$ & $\begin{array}{l}T_{\text {rec }} \text { post exercise: } \\
\text { female }=41.2^{\circ} \mathrm{C}\left(0.7^{\circ} \mathrm{C}\right) \\
\text { male }=41.4^{\circ} \mathrm{C}\left(0.7^{\circ} \mathrm{C}\right) \\
\text { Immersion duration: } \\
{ }^{\text {a }} \text { female }=10.90 \mathrm{~min} ; \\
\text { male }=10.45 \mathrm{~min} . \\
T_{\text {rec }} \text { cooling rate: } \\
\text { female }=0.22(0.10)^{\circ} \mathrm{C} / \mathrm{min} \text {; } \\
\text { male }=0.22(0.12)^{\circ} \mathrm{C} / \mathrm{min} .\end{array}$ & $\begin{array}{l}T_{\text {rec }} \text { post exercise: } \\
\text { female }=39.56^{\circ} \mathrm{C}\left(0.07^{\circ} \mathrm{C}\right) \\
\text { male }=39.57^{\circ} \mathrm{C}\left(0.06^{\circ} \mathrm{C}\right) \\
\text { Immersion duration: } \\
\text { female }=10.89(4.49) \mathrm{min} \\
\text { male }=18.13(4.47) \mathrm{min} . \\
T_{\text {rec }} \text { cooling rate: } \\
\text { female }=0.22(0.07)^{\circ} \mathrm{C} / \mathrm{min} \text {; } \\
\text { male }=0.12(0.03)^{\circ} \mathrm{C} / \mathrm{min} .\end{array}$ \\
\hline Conclusions & $\begin{array}{l}\text { The female with EHS cooled } 35 \% \\
\text { faster than the males with EHS. }\end{array}$ & $\begin{array}{l}\text { No differences were found for cooling } \\
\text { rates between male and female athletes } \\
\text { suffering from EHS. }\end{array}$ & $\begin{array}{l}\text { Hyperthermic females cooled } \\
83 \% \text { faster than hyperthermic males. }\end{array}$ \\
\hline
\end{tabular}

Abbreviations: BSA/LBM, body surface area-to-lean body mass ratio; BSA/M, body surface area-to-mass ratio; CWI, cold-water immersion; EHS, exertional heat stroke; ht, height; IWI, ice water immersion; LBM, lean body mass; $T_{\text {rec }}$, rectal temperature; $\mathrm{VO}_{2}$ max, maximum oxygen consumption. Note: All data are reported as mean (SD) with the exception of Armstrong et $\mathrm{al}^{3}$.

${ }^{\mathrm{a}}$ Immersion duration calculated using the following formula: (mean $T_{\text {rec }}$ postexercise $-38.8^{\circ} \mathrm{C}$ )/mean cooling rate.

\section{Predetermined Inclusion and Exclusion Criteria}

\section{Inclusion}

- Following exercise, subjects were hyperthermic with a $T_{\text {rec }} \geq$ $39.5^{\circ} \mathrm{C}\left(103.1^{\circ} \mathrm{F}\right)$.

- Studies used CWI $\left(\leq 20^{\circ} \mathrm{C}\left[68^{\circ} \mathrm{F}\right]\right)$ to treat hyperthermia.

- Body core temperature was measured with $T_{\text {rec }}$ since this is the only valid, clinically useful body temperature site for an exercising human. ${ }^{6}$

- Limited to studies published in English in the last 15 years (1993-2018).
- Limited to studies classified as Oxford Centre for EvidenceBased Medicine level 3 or higher.

\section{Exclusion}

- Studies that did not test both male and female subjects or differentiate cooling rates by gender.

- Studies that measured body core temperature by oral, axillary, esophageal, tympanic, or temporal thermometry.

- Studies that cooled hyperthermic subjects by other means (eg, cooling vests, passive cooling, ice towels).

- Studies that used percooling (ie, cooling during exercise) or precooling (ie, cooling before exercise). 


\section{Table 2 Summary of Study Designs of Articles Retrieved}

\begin{tabular}{lcc}
\hline Author & Study design & Level of evidence $^{\mathbf{a}}$ \\
\hline Lemire et al $^{2}$ & Quasi-experimental & 3 \\
${\text { Armstrong et } \mathrm{al}^{3}}^{3}$ & Retrospective cohort & 3 \\
Demartini et al & Retrospective cohort & 3 \\
\hline
\end{tabular}

${ }^{\text {a }}$ Level of evidence assessed using the Oxford Centre for Evidence-Based Medicine 2011 criteria.

\section{Results of Search}

Two retrospective cohort studies ${ }^{3,4}$ on EHS victims and 1 quasiexperimental laboratory study ${ }^{2}$ met the predetermined inclusion and exclusion criteria. Each study was reviewed and independently categorized using the 2011 Oxford Centre for Evidence-Based Medicine (Table 2).

\section{Best Evidence}

The studies in Table 2 were identified as the best evidence and selected for inclusion in this CAT. These studies were included because they were considered level 3 evidence or higher and included data to allow comparison of gender differences in CWI $T_{\text {rec }}$ cooling rates.

\section{Implications for Practice, Education, and Future Research}

Two main clinical observations can be derived from this CAT. First, hyperthermic male and female athletes do not have similar $T_{\text {rec }}$ cooling rates. Hyperthermic females included in this CAT cooled $\sim 33 \%$ faster than males. Males required CWI for 4.3 (3.0) minutes longer than females. Second, $T_{\text {rec }}$ cooling rates for men and women were either acceptable $\left(0.08-0.15^{\circ} \mathrm{C} / \mathrm{min}\right)$ or ideal $\left(>0.15^{\circ} \mathrm{C} / \mathrm{min}\right) .^{5}$ All 3 studies $^{2-4}$ observed ideal cooling rates for females, whereas only 2 studies $^{3,4}$ observed ideal cooling rates in males. In 1 study, ${ }^{2}$ males cooled at only acceptable $T_{\text {rec }}$ cooling rates. These results suggest that no additional precautions need to be taken based on gender; however, clinicians should be aware that males may cool slightly slower than females when being treated with CWI.

The primary reason for differences in $T_{\text {rec }}$ cooling rates between genders is likely related to body surface area (BSA), lean body mass (LBM), and body surface area-to-lean body mass (BSA/LBM) ratios. Women, typically, have higher BSA than males. $^{7}$ Thus, females may have a greater capacity to dissipate heat by nonevaporative mechanisms during CWI. Conversely, males are typically heavier and have more LBM than females, ${ }^{2,7}$ which would tend to favor higher metabolic activity and slower cooling rates during CWI. Collectively, this means BSA/LBM ratios tend to be higher in women than men. Several investigators ${ }^{2,8}$ have noted relationships between the BSA/LBM ratio and $T_{\text {rec }}$ cooling rates of hyperthermic subjects. Friesen et $\mathrm{al}^{8}$ observed male subjects with a high BSA/LBM cooled 1.7 times faster than males with a low BSA/LBM. Similarly, Lemire et $\mathrm{al}^{2}$ hypothesized that females cooled faster than males because of differences in BSA/ LBM ratios, since the body surface area-to-mass (BSA/M) ratio and BSA were matched between genders. In fact, BSA/LBM was highly correlated with the CWI $T_{\text {rec }}$ cooling rate $(r=.7)$ when gender data was pooled. ${ }^{2}$ Future research should confirm Friesen et al' $s^{8}$ observations in female subjects to provide greater evidence for the contribution of the $\mathrm{BSA} / \mathrm{LBM}$ ratio to $T_{\text {rec }}$ cooling rates.
Two other minor variables may explain why females cooled faster than males. First, females, in general, have higher adiposity than males. ${ }^{2,7,9}$ However, simply having more adipose tissue is an unlikely explanation for differences in cooling rate between genders. A difference of $10 \%$ adiposity did not affect $T_{\text {rec }}$ cooling rates in hyperthermic men cooled in $8^{\circ} \mathrm{C}$ water $(13 \%$ body fat $=0.23$ $[0.09]^{\circ} \mathrm{C} / \mathrm{min} ; 23 \%$ body fat $\left.=0.20[0.09]^{\circ} \mathrm{C} / \mathrm{min}\right) .{ }^{10}$ However, individuals with more fat mass tend to shiver less during cold exposure, which may result in less metabolic activity in the lean tissue and may result in faster cooling rates. ${ }^{2}$ The influence of adiposity on $T_{\text {rec }}$ cooling rates in hyperthermic men and women with $>25 \%$ body fat has not yet been tested. Second, increases in circulating plasma hormones, especially during the luteal phase of menses, may impact the sensitivity of the shivering response, skin vasoconstrictor response, and/or metabolic activity in women. ${ }^{11}$ Experiments that attempt to control resting body core temperature typically test females during their follicular phase to decrease variability and these hormonal responses. Thus, $T_{\text {rec }}$ cooling rates of women tested during the follicular phase are likely to be less impacted by menses than those of women tested in the luteal phase.

We acknowledge 2 main limitations of our CAT. First, only one of our studies ${ }^{2}$ reported subjects' mass, body fat, BSA/M ratio, and $\mathrm{BSA} / \mathrm{LBM}$ ratio. Therefore, it was not possible to compare the effects of anthropometric factors as they relate to gender between all 3 studies in our CAT. Because only 1 study $^{2}$ controlled for anthropomorphics between genders, and these factors greatly influence $T_{\text {rec }}$ cooling, ${ }^{8,7}$ we placed greater weight on the results of this study ${ }^{2}$ for the final conclusion in our CAT. Second, while Armstrong et $\mathrm{al}^{3}$ had 4 females diagnosed with EHS in their study, only 1 was included in the CWI treatment group. Consequently, we were only able to compare the $T_{\text {rec }}$ cooling rates of the lone female subject to the 13 male EHS victims who were also treated with CWI.

In conclusion, hyperthermic males and females (some with EHS) have different CWI $T_{\text {rec }}$ cooling rates. Hyperthermic females cooled faster than males, which is likely attributed to their higher BSA/LBM ratio. However, future research may wish to answer the following questions: (1) Do females with different BSA/LBM ratios cool at different rates like their male counterparts? ${ }^{8}$ (2) When BSA/LBM ratios are matched between men and women, are $T_{\text {rec }}$ cooling rates equivocal? (3) What is the effect of $>25 \%$ body fat on $T_{\text {rec }}$ cooling rates in men and women? Regardless of differences in $T_{\text {rec }}$ cooling rates between genders, the cooling rates were either acceptable or ideal $^{5}$ in all studies examined. The fact that $100 \%$ of the men and women who experienced EHS $(n=295)$ in both retrospective cohort studies $^{3,4}$ survived without any noted complications attests to the lifesaving capabilities of immediate CWI. Therefore, we conclude CWI is highly effective, regardless of gender, and must be the clinical gold standard for treating EHS victims. This CAT should be reviewed and revised upon the completion of additional studies as they relate to $T_{\text {rec }}$ cooling rates between genders.

\section{References}

1. Casa DJ, DeMartini JK, Bergeron MF, et al. National athletic trainers' association position statement: exertional heat illnesses. J Athl Train. 2015;50:986-1000. PubMed ID: 26381473 doi:10.4085/1062-605050.9.07

2. Lemire BB, Gagnon D, Jay O, Kenny GP. Differences between sexes in rectal cooling rates after exercise-induced hyperthermia. Med Sci Sports Exerc. 2009;41:1633-1639. PubMed ID: 19568196 doi:10. 1249/MSS.0b013e31819e010c 
3. Armstrong L, Crago A, Adams R, Roberts W, Maresh C. Whole-body cooling of hyperthermic runners: comparison of two field therapies. Am J Emerg Med. 1996;14:355-358. PubMed ID: 8768154 doi:10. 1016/S0735-6757(96)90048-0

4. DeMartini JK, Casa DJ, Stearns RL, et al. Effectiveness of CWI in the treatment of EHS at the Falmouth Road Race. Med Sci Sports Exerc. 2015;47:240-245. PubMed ID: 24983342 doi:10.1249/MSS. 0000000000000409

5. McDermott BP, Casa DJ, Ganio MS, et al. Acute whole-body cooling for exercise-induced hyperthermia: a systematic review. J Athl Train. 2009; 44:84-93. PubMed ID: 19180223 doi:10.4085/1062-6050-44.1.84

6. Casa DJ, Becker SM, Ganio MS, et al. Validity of devices that assess body temperature during outdoor exercise in the heat. J Athl Train. 2007;42:333-342. PubMed ID: 18059987

7. Anderson GS, Ward R, Mekjavic IG. Gender differences in physiological reactions to thermal stress. Eur J Appl Physiol. 1995;71:95101. doi:10.1007/BF00854965
8. Friesen BJ, Carter MR, Poirier MP, Kenny GP. Water immersion in the treatment of exertional hyperthermia: physical determinants. Med Sci Sports Exerc. 2014;46:1727-1735. PubMed ID: 24784433 doi:10.1249/MSS.0000000000000292

9. Tikuisis P, Jacobs I, Moroz D, Vallerand AL, Martineau L. Comparison of thermoregulatory responses between men and women immersed in cold water. J Appl Physiol. 2000;89:1403-1411. PubMed ID: 11007575 doi:10.1152/jappl.2000.89.4.1403

10. Lemire BB, Gagnon D, Jay O, Dorman L, Ducharme MB, Kenny GP. Influence of adiposity on cooling efficiency in hyperthermic individuals. Eur J Appl Physiol. 2008;104:67-74. PubMed ID: 18542989 doi:10.1007/s00421-008-0780-0

11. Castellani JW, Young AJ. Human physiological responses to cold exposure: acute responses and acclimitization to prolonged exposure. Auto Neuro. 2016;196:63-74. doi:10.1016/j.autneu.2016. 02.009 